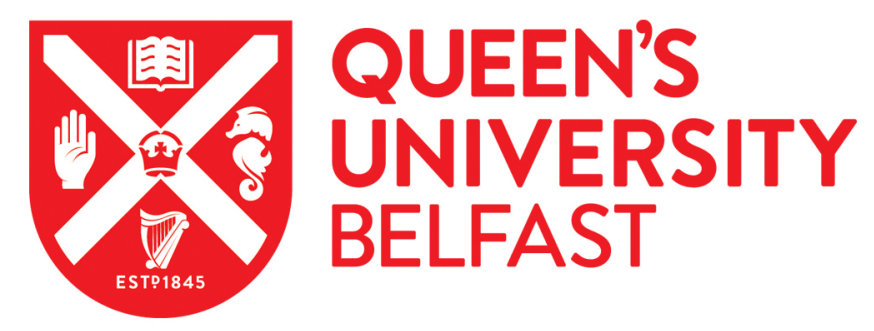

\title{
Manufacturing practices and servitization: the role of mass customization and product innovation capabilities
}

Qi, Y., Mao, Z., Zhang, M., \& Guo, H. (2020). Manufacturing practices and servitization: the role of mass customization and product innovation capabilities. International Journal of Production Economics.

https://doi.org/10.1016/j.ijpe.2020.107747

Published in:

International Journal of Production Economics

Document Version:

Peer reviewed version

Queen's University Belfast - Research Portal:

Link to publication record in Queen's University Belfast Research Portal

Publisher rights

Copyright 2020 Elsevier B.V.

This manuscript is distributed under a Creative Commons Attribution-NonCommercial-NoDerivs License

(https://creativecommons.org/licenses/by-nc-nd/4.0/), which permits distribution and reproduction for non-commercial purposes, provided the author and source are cited.

\section{General rights}

Copyright for the publications made accessible via the Queen's University Belfast Research Portal is retained by the author(s) and / or other copyright owners and it is a condition of accessing these publications that users recognise and abide by the legal requirements associated with these rights.

Take down policy

The Research Portal is Queen's institutional repository that provides access to Queen's research output. Every effort has been made to ensure that content in the Research Portal does not infringe any person's rights, or applicable UK laws. If you discover content in the Research Portal that you believe breaches copyright or violates any law, please contact openaccess@qub.ac.uk. 


\title{
Manufacturing practices and servitization: the role of mass customization and product innovation capabilities
}

\begin{abstract}
Servitization has been viewed as an important method for manufacturers to gain competitive advantages. The purpose of the study is to empirically examine the effects of lean and agile practices as well as mass customization and product innovation capabilities on the implementation of servitization. The hypotheses are empirically examined using structural equation modeling with data collected from 647 manufacturers. The results show that product innovation capability directly improves servitization. Although the direct effect of mass customization capability on servitization is not significant, it improves servitization indirectly through product innovation capability. The findings also reveal that the direct impacts of lean and agile practices on servitization are not significant. Lean and agile practices affect servitization indirectly through product innovation capability, whereas the indirect effects of lean and agile practices on servitization through mass customization capability are not significant. Therefore, this study draws the conclusions that a manufacturer should develop mass customization and product innovation capabilities simultaneously when implementing servitization. Moreover, a manufacturer should also invest on lean and agile practices and product innovation capability at the same time when transforming to a service-based business model to cultivate their synergies on servitization.
\end{abstract}

Keywords: servitization, lean, agile, mass customization capability, product innovation capability 


\section{Introduction}

Manufacturers are facing intensified competition in global markets due to commoditization of products (Baines et al., 2009; Saccani et al., 2014). Modern manufacturing is now seen to extend beyond tangible goods production. Currently, service-oriented business models are accepted as essential to industrial success (Opresnik and Taisch, 2015). Integrating intangible services and tangible products has become a popular strategy for manufacturers to differentiate and gain competitive advantages (Visnjic and van Looy, 2013). Manufacturers are offering product-service systems and integrated solutions and are adopting servitization (Vandermerwe and Rada, 1988). Servitization has become a critical issue for manufacturers competing in global markets. It is considered an important way for manufacturers to create value for customers. Over one-third of large manufacturers offer services, and that proportion increases to almost $60 \%$ in Western economies (Neely, 2008). A report of the Organization for Economic Cooperation and Development (OECD) also shows that when measuring trade in value-added products, almost $70 \%$ of the world's trade is related to services (OECD, 2018).

Although studies have demonstrated the benefits of servitization to product development, firm performance and customer value (Saccani et al., 2014; Zhang et al., 2017), researchers still argue that a firm's profits gained from servitization may be lower than the costs of service provision (i.e., the service paradox) (Gebauer et al., 2005). Moreover, empirical evidence suggests that manufacturing practices and operational capabilities play crucial roles in the implementation of servitization (Green et al., 2017). For example, Dell implemented servitization by adopting a customer-centric business model based on direct customer contact. The adoption of lean practices in supply chain management, the development of product customization capability, and operational excellence in manufacturing and logistics have been viewed as the main enablers for the business model (Perona et al., 2017). Caterpillar implemented servitization by offering integrated solutions encompassing a set of 
services and products. The company has developed innovative products and adopted advanced operational practices to develop well-integrated spare part supply chains and to achieve operational excellence in spare part logistics and distribution, which have been viewed as the main enablers of servitization (Perona et al., 2017). Therefore, examining the mechanisms through which manufacturing practices and operational capabilities influence servitization can help manufacturers understand the antecedents of servitization and design a system to resolve the service paradox (Gebauer et al., 2005; Lee et al., 2016).

The resource-based view (RBV) provides a useful perspective to investigate the strategic resources with the potential to deliver comparative advantages and superior performance to a firm (Barney, 1991). Based on the RBV, we focus on firms' internal resources and capabilities that can influence the implementation of servitization (Barney, 1991). From an operational point of view, manufacturing practices are the resources of a firm because they enable the firm to accumulate knowledge and develop capabilities (Peng et al., 2008). We focus on lean and agile practices because lean practices are positively associated with customer satisfaction (Hines et al., 2004) and agile practices can reorganize resources to satisfy changing customer needs (Leite and Braz, 2016), both of which are resources for a firm and critical for servitization (Baines et al., 2009; Lee et al., 2016). In addition, lean and agile practices represent two main philosophies for organizing production and strategies for manufacturers to gain competitive advantages (Qi, 2006). We also focus on mass customization and product innovation capabilities because researchers indicate that they are critical capabilities for implementing servitization (Green et al., 2017; Sousa and da Silveira, 2019; Visnjic and van Looy, 2013). Mass customization capability enables a manufacturer to provide customized products and services to individuals without significantly increasing costs and lead times, and it has been identified as a core operational capability for a manufacturer to compete in rapidly changing environments (Liu et al., 2012; Zhang et al., 2014). We focus on mass customization capability because it prompts manufacturers to use services and offer product-service 
systems when customizing for customers (Salvador et al., 2009). Product innovation capability promotes servitization by enabling a company to design product architecture and components to integrate services and provide solutions to customers (Vandermerwe and Rada, 1988; Rabetino et al., 2018). We focus on product innovation capability because it allows a manufacturer to introduce new products to facilitate the transition to a service-oriented business model (Baines et al., 2017).

The objective of this study is to empirically investigate the joint effects of lean and agile practices and mass customization and product innovation capabilities on servitization. This study answers the call for more confirmatory and quantitative research (Rabetino et al., 2018) on servitization using large-scale international samples from diverse sectors (Sousa and da Silveira, 2017). It contributes to the literature by providing insights into the direct and indirect relationships among manufacturing practices, operational capabilities and servitization. The findings enhance existing knowledge on the capability antecedents of servitization by investigating the joint effects of mass customization and product innovation capabilities (Sousa and da Silveira, 2017). The results can improve current understandings of the relationships between customization and servitization, extending the findings of Sousa and da Silveira (2019). Moreover, this study clarifies the mechanisms through which lean and agile practices and mass customization and product innovation capabilities affect servitization, which provides empirical evidence of the supportive practices and assets of the implementation of servitization (Green et al., 2017) and extends recent debates on the service-based business models of manufacturers (Rabetino et al., 2018). The findings can add clarity for the micro-foundation and success factors for servitization (Baines et al., 2017). Therefore, by empirically investigating the joint effects of manufacturing practices and operational capabilities, this study sheds light on how manufacturers can efficiently and effectively configure resources and capabilities to transform to a service-oriented business model (Baines et al., 2017; Rabetino et al., 2018). 


\section{Research hypotheses}

\subsection{Resource-based view}

The RBV explains that the basis for the competitive advantages of a firm lies primarily in the application of the resources at the firm's disposal (Barney, 1991). Resources refer to tangible and intangible assets, such as money, people, technology, routines, knowledge and relationships, that are inherent to a firm (Peteraf, 1993). Firms are heterogeneous and have different capabilities because they have unique bundles of resources (Peteraf, 1993), which are valuable, difficult to imitate or substitute and rare.

Peng et al. (2008) define practices as what firms consistently do as organizational routines. Furthermore, based on the RBV, Peng et al. (2008) argue that those routines are the resources for a firm to create static or dynamic capabilities. In this study, we take a similar view to define lean and agile practices as two bundles of practices and organizational processes or routines (Qi, 2006). Lean practices focus on cost efficiency, standardization, and identification and elimination of waste (Shah and Ward, 2007). Agile practices focus on differentiation, flexibility and satisfying customer needs in changing business environments (Sharifi and Zhang, 2001). Both lean and agile practices rely on a system of technologies, processes, approaches and tools and are positively related to operational capabilities, although they affect operational capabilities in different ways. Moreover, mass customization capability allows a manufacturer to provide tailored products in an efficient way (Zhang et al., 2014), and product innovation capability helps a manufacturer introduce new products quickly at low cost (Kim et al., 2012). Researchers argue that mass customization and product innovation capabilities allow a manufacturer to enhance multiple dimensions of operational performances that improve firm performance and customer satisfaction and hence yield competitive advantages (Alegre and Chiva, 2008; Zhang et al., 2015a).

\subsection{Servitization}

Servitization refers to the provision of customer-focused services based on the 
production of products (Neely, 2008; Visnjic and van Looy, 2013). By integrating services with goods and knowledge, servitization enables manufacturers to create additional value for customers and differentiate products by including services to avoid the commoditization trap (Opresnik and Taisch, 2015; Bustinza et al., 2013). Therefore, servitization has become an effective tool to gain competitive advantages by increasing customer satisfaction (Saccani et al., 2014) and promoting sustainable growth (Kowalkowski et al., 2017). Customization and innovation have been identified as important drivers of servitization (Sousa and da Silveira, 2019; Kowalkowski et al., 2017). Additionally, prior studies have linked manufacturing practices with the implementation of servitization (Dowlatshahi and Cao, 2006; Resta et al., 2015).

Although existing literature has argued that the implementation of servitization requires manufacturers to develop capabilities (Baines et al., 2009; Gebauer et al., 2005; Kowalkowski et al., 2017; Sousa and da Silveira, 2017; Opresnik and Taisch, 2015), there is limited empirical evidence on the joint effects of manufacturing practices and capabilities on the implementation of servitization. Based on the RBV, this study develops a practices-capabilities-servitization framework to investigate the joint effects of lean and agile practices and mass customization and product innovation capabilities on servitization. Figure 1 shows the conceptual framework.

$<<<<<<<<<<<$ Insert Figure 1 about here $>>>>>>>>>>>$

\subsection{Lean and agile practices}

Lean practices originate from the Toyota Production System, and the basis of lean is the elimination of all kinds of waste (Hines et al., 2004). Lean practices are always implemented in bundles, and quality management, cost and lead-time reduction and processing technologies have been identified as the key components of lean practices (Hines et al., 2004; Shah and Ward, 2007). They are designed to achieve balanced work flows in a predictable and stable environment and can improve product quality and productivity as well as reduce cycle times, inventory levels and costs (Shah and Ward, 2007). 
Existing studies have highlighted that lean practices have positive effects on servitization (Baines et al., 2009; Resta et al., 2015). Specifically, lean practices help manufacturers configure internal resources to achieve operational excellence (Qi, 2006). Quality management programs improve customer satisfaction and the efficiency of production processes. They incorporate systems and tools that enable manufacturers to continuously improve products and prevent defects (Zhang et al., 2019). Cost and lead-time reduction programs help manufacturers eliminate unnecessary elements in processes to reduce production lead times and costs (Shah and Ward, 2007). Processing technologies also enable manufacturers to identify and analyze the value stream for each product and make production processes flow without interruption. Therefore, lean practices allow manufacturers to develop systems and technologies to improve the speed and efficiency of production processes. As a result, manufacturers can produce standard products with lower costs and higher quality, which drives them to add services and implement servitization to differentiate products (Baines et al., 2009). Therefore, we propose the following hypothesis.

H1: Lean practices directly improve the implementation of servitization.

Agile practices focus on the integration of reconfigurable resources and best practices in a knowledge-rich environment to provide customer-driven products in a fast-changing market (Gunasekaran, 1998). They allow manufacturers to add value for customers, cooperate to enhance competitiveness and leverage the impacts of people and information (Dowlatshahi and Cao, 2006). A flexible workforce, customer support systems and internal and external integration have been identified as important agile practices (Inman et al., 2011; Leite and Braz, 2016). Empirical evidence exists that agile practices can lead to higher operational (Inman et al., 2011; Leite and Braz, 2016) and financial performance (Dowlatshahi and Cao, 2006) and improve competitiveness (Gunasekaran, 1998) by responding to unanticipated environments quickly and efficiently.

Agile practices help manufacturers profit from rapidly changing and continuously fragmenting markets by offering high-performance products 
(Gunasekaran, 1998). A flexible workforce enables a manufacturer to create a system that rapidly reconfigures and reallocates human resources (Inman et al., 2011). Customer support helps manufacturers quickly respond to market changes and determine future customer expectations (Dowlatshahi and Cao, 2006). Integration between manufacturing and design departments allows employees to exchange information and performance feedback and make joint decisions (Zhang et al., 2018). Customer and supplier process integration helps a manufacturer acquire insights into supply-chain partners' processes, capabilities and constraints and share knowledge, enabling more effective planning and forecasting and better product and process design (Zhang et al., 2018). Therefore, agile practices enable manufacturers to develop knowledge and processes to understand customer requirements and quickly respond to changes in the environment, which helps manufacturers create service-focused solutions and implement servitization (Leite and Braz, 2016). Therefore, we propose the following hypothesis.

$\mathrm{H} 2$ : Agile practices directly improve the implementation of servitization.

\subsection{Mass customization capability}

Mass customization capability can be defined as the capability to reliably produce a high volume of different product options for a relatively large market and to quickly adjust product and process design according to customer demand, without substantial tradeoffs in cost, delivery or quality (Liu et al., 2012; Zhang et al., 2014). Mass customization capability has four aspects: high-volume customization (the ability to aggregate individual customers' demands into large-batch common part production), customization cost efficiency (the ability to provide customized products at a price similar to mass production), customization responsiveness (the ability to reduce total lead-time for customized product delivery) and customization quality (the ability to manage and guarantee the quality level of every customized product) (Zhang et al., 2015a).

Existing empirical evidence suggests that mass customization capability can increase value to customers, customer satisfaction and customer quality integration 
(Liu et al., 2012; Zhang et al., 2019). Therefore, mass customization capability helps a manufacturer build close relationships with customers to obtain knowledge about customer requirements and changes in markets (Salvador et al., 2009; Zhang et al., 2015b), which informs the manufacturer's service offerings (Zhang et al., 2017). In addition, when developing mass customization capability, a manufacturer may customize services around standard products (Salvador et al., 2009). As a result, mass customizers tend to add services and offer customized solutions that promote the implementation of servitization (Baines et al., 2009; Opresnik and Taisch, 2015). Therefore, we propose the following hypothesis.

H3: Mass customization capability directly improves the implementation of servitization.

Quality management programs enable different functional departments to coordinate decisions, leading to stable and efficient processes and improved internal visibility (Zhang et al., 2019), which ensure a high level of quality when product and production variety increases significantly. Cost and lead-time reduction programs can speed up internal operations and accelerate physical flows (Zhang et al., 2015b). They also reduce the levels of raw materials, work-in-process and finished product inventory, resulting in lower production costs and fewer defects (Resta et al., 2015). Thus, a manufacturer can provide customized products in a cost-effective manner. Processing technologies enhance manufacturing precision and help a manufacturer fabricate products in large batches. They decrease process variability and automate planning and production, which enable fast and efficient manufacturing operations (Hines et al., 2004). As a result, lean practices can improve mass customization capability, which enhances servitization. Therefore, we propose the following hypothesis.

H4: Lean practices improve the implementation of servitization indirectly through mass customization capability.

Agile practices enable a manufacturer to respond quickly and effectively to market changes and be proactive in exploiting and taking advantage of these changes; 
thus, these practices are a necessary factor for mass customization capability development (Brown and Bessant, 2003). A flexible workforce and integration between manufacturing and design processes help a manufacturer develop robust processes to reuse or recombine existing organizational resources to fulfill a stream of differentiated customer needs (Salvador et al., 2009). Customer support and customer process integration provide mechanisms for interacting with customers and obtaining specific information (Zhang et al., 2015b). They enable knowledge to flow freely between customers and manufacturers, which helps the manufacturers fully understand market changes and determine what customers truly want (Brown and Bessant, 2003; Zhang et al., 2015a). In addition, supplier process integration provides opportunities to improve transactional efficiencies, solve problems, identify new product ideas, reduce production lead times and speed up new product introduction and delivery (Zhang et al., 2018). Thus, customization responsiveness, quality and cost efficiency can be improved. As a result, agile practices enhance mass customization capability, which improves servitization. Therefore, we propose the following hypothesis.

H5: Agile practices improve the implementation of servitization indirectly through mass customization capability.

\subsection{Product innovation capability}

Product innovation capability refers to the ability to introduce new products to meet customer demand (Kim et al., 2012). It allows a manufacturer to generate, adopt and implement new ideas to change the manufacturer's offerings to its customers (Slater et al., 2014; Zhang et al., 2015b). Product innovation capability can help a manufacturer minimize product development time and maximize new product introduction frequency (Alegre and Chiva, 2008). Therefore, it can be reflected by the number of new products, speed and frequency of new product introduction, and total sales stemming from new products (Kim et al., 2012; Zhang et al., 2015a). New products may incorporate substantially different technology from that of existing products or provide new features, improvements, or benefits to existing technology in the current 
market (Kim et al., 2012; Slater et al., 2014). The integration of internal and external resources and knowledge plays a critical role in the development of product innovation capability and the management of the process from concept generation to product commercialization.

Product innovation capability helps a manufacturer develop new applications of knowledge, methods and skills that can generate enhanced products to meet customer demand and market needs and bring unprecedented consumer benefits (Kim et al., 2012; Slater et al., 2014). It also allows the manufacturer to efficiently manage a wide variety of products, develop market and technological knowledge, and build close and cooperative relationships among employees (Alegre and Chiva, 2008; Zhang et al., 2015a). New products can expand manufacturers' knowledge bases and create new product architecture to offer integrated products and services (Baines et al., 2017). As a result, product innovation capability enables a manufacturer to respond quickly to customer requirements through the development and delivery of value-added services or product-service systems, promoting the implementation of servitization (Neely, 2008). Therefore, we propose the following hypothesis.

H6: Product innovation capability directly improves the implementation of servitization.

Quality management programs help a manufacturer continuously improve products and processes, which then increases the number and frequency of new products introduced (Zhang et al., 2019). Cost and lead-time reduction programs can reduce the costs and improve the speed of new product development, thus increasing the profits stemming from new products and the speed of new product introduction (Alegre and Chiva, 2008; Shah and Ward, 2007). Moreover, processing technologies allow a manufacturer to automate product reengineering and develop and accumulate technological knowledge, leading to enhanced product innovation capability (Kim et al., 2012). In addition, lean practices encourage employees to work together and build cooperative relationships and culture, which help a manufacturer acquire, assimilate and apply knowledge to develop new products (Slater et al., 2014; Zhang et al., 2015a). 
As a result, lean practices improve product innovation capability, which enhances servitization. Therefore, we propose the following hypothesis.

H7: Lean practices improve the implementation of servitization indirectly through product innovation capability.

Customer support allows a manufacturer to build trust with customers and quickly obtain accurate information about customer preferences and market changes (Zhang et al., 2015b). A flexible workforce and manufacturing and design integration provide the intangible resources that can create new technological knowledge, thus speeding up innovation processes and stimulating innovation outcomes (Brown and Bessant, 2003; Dowlatshahi and Cao, 2006). Supplier and customer process integration can assist a manufacturer in addressing resource gaps, such as knowledge, skills and expertise, which prevent rigidity and encourage innovative behavior (Zhang et al., 2018). The manufacturer and its partners can then develop a common understanding of how to develop new products to respond to changes in markets (Alegre and Chiva, 2008). Agile practices enable a manufacturer to integrate internal and external resources and create a flexible system that can increase the speed and frequency of new product development. As a result, agile practices improve product innovation capability, which is positively associated with servitization. Therefore, we propose the following hypothesis.

H8: Agile practices improve the implementation of servitization indirectly through product innovation capability.

The ability to customize products while maintaining high volumes drives a manufacturer to use common parts and modules and identify the commonalities of customer requirements, which can reduce new product development costs and speed up new product introduction (Alegre and Chiva, 2008; Zhang et al., 2014). The ability to customize products without significantly increasing cost enables a manufacturer to develop flexible production and delivery systems, which help it create technological knowledge that increases the number and frequency of new products introduced (Zhang et al., 2015b). The ability to respond to customization demands quickly 
facilitates interactions with customers, which allow the manufacturer to elicit information from customers (Slater et al., 2014; Zhang et al., 2015a). Moreover, customizing products with consistent quality can improve customer satisfaction, which assists a manufacturer in developing long-term relationships with customers (Zhang et al., 2019). Mass customization capability enhances a manufacturer's knowledge stock regarding customers and markets (Zhang et al., 2015a). As a result, mass customization capability can significantly contribute to product innovation capability, which improves servitization. Therefore, we propose the following hypothesis.

H9: Mass customization capability improves the implementation of servitization indirectly through product innovation capability.

\section{Research method}

\subsection{Data}

This study used data collected from the Global Manufacturing Research Group (GMRG) Round 5.0 survey to test the hypotheses (Durach and Wiengarten, 2017; Onofrei et al., 2019). The GMRG is run by a worldwide group of researchers dedicated to the study and improvement of manufacturing practices globally (Whybark, 1997). The GMRG developed its database using a common survey instrument and a cross-sectional design for all countries (Durach and Wiengarten, 2017; Onofrei et al., 2019). The measurement items were developed based on well-grounded theories and feedback from previous GMRG surveys and pilot tested by multiple academics within the research group via group member meetings and industrial interviews (Onofrei et al., 2019). The standardized questionnaires (developed in English) were administered by the researchers using their native languages (Whybark, 1997). Rigorous translations and back-translations were performed to ensure the equivalence of the questionnaires across different countries (Whybark et al., 2009). The questionnaire included two parts (Whybark et al., 2009). 
The first part was the core module, which was about company demographics, manufacturing practices, competitive goals and performance. The second part contained optional modules addressing specific management issues, such as innovation, manufacturing practices, operational capabilities and supply-chain management.

The data were collected by individual members of the GMRG, who were required to use the most suitable population frame depending on the country-specific circumstances (Durach and Wiengarten, 2017). Each survey administrator received a GMRG start-up package that contained the questionnaire, the data-gathering sheet (where data were stored), the validation sheet (with which data quality could be assessed) and the methodology sheet (which described how data collection was performed) (Onofrei et al., 2019). The unit of analysis was a manufacturing plant. The managers or directors of the manufacturing plants were the key respondents because they possessed comprehensive information and knowledge of their plants' manufacturing processes and operations (Whybark et al., 2009). Up to six managers were involved in completing the questionnaires in each country (Durach and Wiengarten, 2017).

Each survey administrator individually decided on the most appropriate approach for data collection. Most of the questionnaires were administered during an on-site personal interview (43\%), followed by completion on the Internet (29\%) and mail surveys (23\%) (Onofrei et al., 2019). A common GMRG data-coding program was used to check the completed questionnaires (Whybark, 1997). This program took the survey responses as inputs (following the format of the English-language questionnaire) and produced a common set of data files. The data were pooled by a central data administrator; checked for reliability, consistency and integrity; and redistributed to participating researchers (Schoenherr and Narasimhan, 2012). After data cleaning, the GMRG had collected a total of 647 valid responses from 10 countries using the innovation and mass customization modules. Using the independent-sample $\mathrm{T}$ tests, researchers compared the responses attributed to early 
and late respondents in every region (Schoenherr and Narasimhan, 2012). The results show that there are no significant differences between these two groups; hence, nonresponse bias is not a serious problem (Schoenherr and Narasimhan, 2012). Table 1 shows the demographic information of the plants.

$\langle<<<<<<<<<<$ Insert Table 1 about here $>>>>>>>>>>>$

\subsection{Measurement items}

Lean practices were measured by four items about cost and lead-time reduction programs, quality management programs and processing technologies, which were adapted from Kull et al. (2014) and Shah and Ward (2007). Agile practices were measured by five items assessing the manufacturing practices of a flexible workforce, customer support, integration between manufacturing and design departments and supplier and customer process integration, which were adapted from Dowlatshahi and Cao (2006), Gunasekaran (1998) and Qi (2006). Five items regarding high volume customization, customization cost efficiency, customization responsiveness and customization quality were used to measure mass customization capability, which were fully adopted from Liu et al. (2012) and Zhang et al. (2014). Four items measuring the speed and frequency of new product introduction, the number of new products and the total sales stemming from new products were used to gauge product innovation capability, which were adapted from Kim et al. (2012) and Zhang et al. (2015a). A multiple-item seven-point Likert scale ( 1 = "strongly disagree" or "not at all or far worse"; 7 = "strongly agree" or "to a great extent or far better") was employed for all the constructs. The scales, which consisted of 18 measurement items, are listed in Appendix 1. Furthermore, servitization was measured by the percentage of the total sales coming from services (Neely, 2008; Fang et al., 2008).

Plant size, which was measured by the log-transformation of the number of employees, was included as a control variable in the data analyses because large plants may have more resources, which may affect the implementation of servitization (Neely, 2008). We also controlled for R\&D investment, which was measured by the percentage of total plant annual sales invested in $R \& D$, as plants that had invested 
more may have accelerated the implementation of servitization (Zhang et al., 2015b). The training budget was included as a control variable, which was measured by the ratio of the plant's average training budget for employee education to the total sales because plants with highly trained human resources may develop more knowledge to implement servitization (Baines et al., 2009). The country and industry sectors were also included as control variables. The ten countries were classified into two groups, industrialized countries and emerging countries, because competitive capabilities have greater effects on performance in emerging countries than in industrialized countries (Schoenherr et al., 2012). As the implementation of servitization is influenced by product and process characteristics, industries were classified into those producing industrial products, consumer products and primary products (Brouthers et al., 2005). The sample distributions of countries and industries are shown in Table 1.

Harman's single-factor model was applied using confirmatory factor analysis (CFA) to evaluate the potential impact of the common method bias. The fit indices are $\chi^{2}(135)=3552.55, \chi^{2} / \mathrm{df}=26.32, C F I=0.47, R M S E A=0.2, T L I=0.33 \quad$. The results suggest that the single-factor model is unacceptable (Hu and Bentler, 1999). This study also tested two CFA models: model A only included traits, and model B included both traits and a common method factor. Compared to model A, the fit indices of model B are marginally improved, and the loadings of the factors are consistent. Therefore, common method bias is not a serious concern in this study (Podsakoff et al., 2003).

\subsection{Psychometric tests}

This study used composite reliability and Cronbach's $\alpha$ to evaluate reliability. Appendix 1 shows that the composite reliability values range from 0.85 to 0.95 , and the Cronbach's $\alpha$ values range from 0.76 to 0.93 . These results show that the reliability of the constructs is acceptable.

This study used a CFA method and average variance extracted (AVE) to test the convergent and discriminant validity (Podsakoff et al., 2003). The fit indices of the 
CFA analysis $\left(\chi^{2}(129)=428.33, \chi^{2} / d f=3.33, C F I=0.95, R M S E A=0.06, T L I=0.94\right)$ indicate that the measurement model fits well (Hu and Bentler, 1999). Moreover, the factor loadings range from 0.640 to 0.928 , and the smallest $\mathrm{t}$ value is 17.26 (Appendix 1). Additionally, the AVE values range from 0.58 to 0.82 . These results indicate that the convergent validity is acceptable.

Discriminant validity is demonstrated when the square root of the AVE of each construct is higher than the correlations between the focal constructs and each other (Fornell and Larcker, 1981). Table 2 shows the means and standard deviations of the constructs, their correlations and the square roots of the AVEs. A comparison of the correlations and square roots of the AVEs indicates adequate discriminant validity for all the constructs (Table 2). We also assessed discriminant validity by building a constrained CFA model for every possible pair of constructs, in which the correlations between the paired constructs were fixed at 1.0. This was compared with the original unconstrained model, in which the correlations between constructs were freely estimated. The results show that the smallest chi-square difference is significant at the $\mathrm{p}<0.01$ level, indicating that discriminant validity is ensured (Fornell and Larcker, 1981).

$<<<<<<<<<<<$ Insert Table 2 about here $>>>>>>>>>>$

\section{Analysis and results}

Structural equation modeling with the AMOS 21.0 program and the maximum likelihood estimation method were chosen to test the full model. The results are presented in Figure 2. The model fit indices are $\chi^{2}(255)=735.79, \chi^{2} / d f=2.89, C F I=0.94, R M S E A=0.05, T L I=0.92$, which are acceptable (Hu and Bentler, 1999). The results show that the direct impacts of lean and agile practices on servitization are insignificant, and hence $\mathrm{H} 1$ and $\mathrm{H} 2$ are not supported. The direct relationship between mass customization capability and servitization is not significant. Therefore, H3 is not supported. Product innovation capability positively affects servitization $(b=0.10, \mathrm{p}<0.05)$, which provides support 
for H6. Moreover, the results show that lean practices positively influence product innovation capability $(b=0.15, p<0.05)$ whereas the relationship between lean practices and mass customization capability is not significant. We also find that agile practices significantly influence mass customization capability $(b=0.52, p<0.001)$ and product innovation capability $(\mathrm{b}=0.17, \mathrm{p}<0.05)$. Mass customization capability is positively associated with product innovation capability $(b=0.28, p<0.001)$. In addition, the findings show that plant size negatively affects servitization $(b=-0.22, p$ $<0.001)$, whereas training budget positively affects servitization $(b=0.13, p<0.01)$. Additionally, the findings show that an industrialized country negatively affects servitization $(b=-0.09, p<0.05)$ and consumer products are negatively associated with servitization $(b=-0.22, p<0.05)$. The influences of $R \& D$ budget, industrial products and primary products on servitization are not significant.

\section{$\ll<<<<$ Insert Figure 2 about here $\gg>>>>$}

To further evaluate the joint effects of lean practices, agile practices, mass customization capability and product innovation capability on servitization, we examined the indirect effects of lean and agile practices on servitization through mass customization and product innovation capabilities and the indirect effect of mass customization capability on servitization through product innovation capability. We used the bias-corrected bootstrap method with a 95\% confidence interval and 5000 samples (Preacher and Hayes, 2008). The result demonstrates that the indirect effect of lean practices on servitization through product innovation capability is $0.030(\mathrm{t}=$ $2.309)$, and the bias-corrected $95 \%$ confidence interval is $(0.005,0.057)$; that of the agile practices on servitization through product innovation capability is $0.037(\mathrm{t}=$ $2.279)$, and the bias-corrected $95 \%$ confidence interval is $(0.006,0.070)$; , and that of mass customization capability on servitization through product innovation capability is $0.035(\mathrm{t}=2.185)$, and the bias-corrected $95 \%$ confidence interval is $(0.004,0.066)$. Therefore, H7, H8 and $\mathrm{H} 9$ are supported. We also find that the indirect effect of lean practices on servitization through mass customization capability is $0.012(\mathrm{t}=1.078)$, and the bias-corrected $95 \%$ confidence interval is $(-0.009,0.034)$, and that of agile 
practices on servitization through mass customization capability is $0.014(\mathrm{t}=0.833)$, and the bias-corrected $95 \%$ confidence interval is $(-0.018,0.050)$. Therefore, $\mathrm{H} 4$ and H5 are not supported. The findings reveal that product innovation capability fully mediates the impacts of lean and agile practices and mass customization capability on servitization, whereas mass customization capability does not mediate the impacts of lean and agile practices on servitization.

\section{Discussion and implications}

\subsection{The direct impacts of lean practices}

The results show that lean practices enhance product innovation capability, whereas their effects on mass customization capability and servitization are not significant. Although lean practices can reduce the costs and lead times of service provision (Resta et al., 2015), they focus on standardized services that are pushed to customers. Customers may extract limited value from these services, which may lead to the service paradox (Gebauer et al., 2005; Green et al., 2017; Lee et al., 2016). Therefore, lean practices have mixed effects on servitization. Lean practices aim to develop a value stream in which all kinds of waste in the system are eliminated and to ensure a level schedule in production to maintain competitive advantages through economies of scale in a stable and predictable market (Hines et al., 2004; Resta et al., 2015). Lean practices help a manufacturer maintain a low-cost position relative to competition and focus on providing a flow of standardized goods and services to achieve large-batch and high-quality operations (Shah and Ward, 2007; Zhang et al., 2019). As a result, although lean practices enable manufacturers to control costs and achieve high volume and high quality when mass customizing, they may not be able to address environmental uncertainties or enable a manufacturer to respond swiftly to changes in markets (Liu et al., 2012; Zhang et al., 2015b). Therefore, lean practices do not improve mass customization capability. Lean practices enable a manufacturer to continuously improve its operational performance in terms of cost, speed and quality 
(Shah and Ward, 2007). As a result, a manufacturer can accumulate technological knowledge that can improve product innovation capability.

We suggest that managers adopt lean practices to develop product innovation capability. For example, they may implement quality management programs, such as total quality management and Six Sigma, adopt cost and lead-time reduction programs such as target costing, just-in-time production and Kanban systems, and develop processing technologies, such as automation and information technologies in product manufacturing and production planning and control. However, managers should be warned that lean practices cannot directly improve the development of mass customization capability and the implementation of servitization.

\subsection{The direct impacts of agile practices}

We find that agile practices improve mass customization and product innovation capabilities, whereas their direct effect on servitization is not significant. Agile practices help a manufacturer develop a flexible and reconfigurable network with partners to share competences and market knowledge to survive and prosper in a fluctuating market environment by responding rapidly and cost-effectively to changes (Inman et al., 2011; Sharifi and Zhang, 2001). Although agile practices can make it easier for a manufacturer to offer services to customers, the services are mainly base and intermediate services that focus on product provision and maintenance of product conditions (Baines et al., 2009). As a result, agile practices can help a manufacturer offer product-oriented product-service systems in which the manufacturer sells products in the traditional manner with additional services to guarantee the functionality and durability of the products and facilitate customers' access to them. They may not lead to use-oriented product-service systems in which a manufacturer sells the use by providing bundled tangible and intangible components to support customers' value creation or result-oriented product-service systems in which a seller is paid for the units of service or level of performance delivered to a customer (Baines et al., 2009; Lee et al., 2016). Therefore, agile practices may not directly improve the implementation of servitization. Agile practices allow a manufacturer to collaborate 
with customers and suppliers and build a flexible operations system to profit in a volatile business environment (Gunasekaran, 1998; Leite and Braz, 2016). Cooperation with customers helps a manufacturer obtain knowledge about customers' requirements and changes in the market (Zhang et al., 2018). Cooperation with suppliers and a flexible internal system allow the manufacturer to adapt design, production, logistics and purchasing processes to customize products or develop new products according to that knowledge (Slater et al., 2014; Zhang et al., 2015a). Therefore, agile practices are positively associated with mass customization and product innovation capabilities.

We suggest that managers adopt agile practices to develop mass customization and product innovation capabilities. For example, they may use job rotation to develop multifunctional employees and a flexible workforce, maintain frequent contact with customers, and focus on customers in business planning. Cross-functional teams and interdepartmental meetings should be used to integrate manufacturing and design processes. We also suggest that manufacturers share information with customers and suppliers and creates linkages with them through information technology. Manufacturers should work with customers and suppliers to improve inter-organizational processes. Involving customers and suppliers in internal operations, such as production and new product development, is also important. In addition, we suggest that manufacturers build trust and strategic partnerships with customers and suppliers. However, managers should be warned that agile practices cannot directly lead to the implementation of servitization.

\subsection{The role of mass customization and product innovation capabilities}

The results show that the direct impact of mass customization capability on servitization is not significant. Although adding services has been viewed as an important method for mass customization (Salvador et al., 2009), services are viewed as add-ons, and value is mainly in tangible goods. Mass customization capability cannot help a manufacturer offer advanced services that focus on delivering value through the performance of integrated solutions (Baines et al., 2009). As a result, mass 
customized products are the dominant components in product-service systems, and hence mass customization capability cannot help a manufacturer implement servitization that focuses on selling utility and performance through services (Kowalkowski et al., 2017). Moreover, the results provide a possible explanation for the insignificant indirect effects of lean and agile practices on servitization through mass customization capability. We also find that product innovation capability is positively associated with the implementation of servitization. It allows a manufacturer to redesign product architecture and components so that the manufacturer can provide integrated solutions in which value and benefits are delivered through complementary and mutually supportive products and services (Bustinza et al., 2013). Therefore, product innovation capability helps a manufacturer develop an integrated and marketable package of products and services that is capable of jointly fulfilling customers' needs and delivering value-in-use, facilitating the implementation of servitization.

The findings reveal that mass customization and product innovation capabilities are not independent and that mass customization capability enhances product innovation capability (Zhang et al., 2015a). Mass customization capability enables a manufacturer to elicit and accumulate knowledge about customers and markets that can be used to develop new products (Zhang et al., 2015b). In addition, the results show that product innovation capability fully mediates the impacts of lean and agile practices and mass customization capability on servitization. Although lean and agile practices and mass customization capability help manufacturers offer services, they are offered as additions, such as maintenance, advice and consultancy, and customers mainly pay for products (Gunasekaran, 1998; Salvador et al., 2009). Meanwhile, they help a manufacturer develop product innovation capability by providing technological and market knowledge and responsive and efficient processes and systems. As product innovation capability allows a manufacturer to create integrated solutions, lean and agile practices and mass customization capability improve the implementation of servitization indirectly through product innovation capability. 
We suggest that managers develop product innovation capability to facilitate the implementation of servitization. For example, we recommend that manufacturers invest in physical (advanced information and manufacturing technologies and equipment), human (hiring employees with advanced technical knowledge and new product development experiences) and financial (investments in R\&D) resources for product innovation. A manufacturer should also build collaborative and strategic relationships with partners, such as suppliers, customers, competitors, universities and research institutes, to cooperate on new product development. We also suggest that managers invest in developing mass customization capability. For example, a manufacturer can implement time-based and modularity-based manufacturing practices, sociotechnical work-design practices, organizational learning and supply-chain integration and coordination and build social capital with partners. Furthermore, we suggest that managers invest in lean and agile practices and the development of mass customization and product innovation capabilities simultaneously to fully reap the benefits of their joint effects on servitization. In addition, we find that plant size negatively influences servitization, whereas training budget positively influences servitization. Therefore, we suggest that managers invest in employee training and education. Managers should be aware that large plants must invest more in manufacturing practices and operational capabilities to implement servitization. Moreover, the findings reveal that country and industry affect the implementation of servitization, and hence we suggest managers consider the environmental characteristics of countries and industries when transforming to a service-oriented business model.

\subsection{Theoretical contributions}

This study contributes to the literature in two ways. First, it links servitization with manufacturing practices and operational capabilities (Baines et al., 2009; Visnjic and van Looy, 2013). We find that neither lean nor agile practices have a direct influence on servitization, whereas product innovation capability fully mediates the effects of lean and agile practices on servitization. The mechanisms through which 
manufacturing practices affect servitization are clarified, providing insights into the joint effects of manufacturing practices and operational capabilities on the implementation of servitization. This study thus enhances the current understanding of how lean and agile practices affect the implementation of servitization and demonstrates how to effectively apply manufacturing practices and develop operational capabilities to adopt servitization (Green et al., 2017). The findings suggest that the impacts of manufacturing practices on servitization are transmitted through operational capabilities, which provides empirical support for the practices-capabilities-servitization framework and highlights that manufacturing practices are the foundation for a manufacturer to implement servitization (Peng et al., 2008; Baines et al., 2017). The findings also fill the gap in the extant studies on the relationships between manufacturing practices and servitization and shed light on how to address the service paradox by investing in operational capabilities (Gebauer et al., 2005; Kowalkowski et al., 2017; Lee et al., 2016).

Second, this study enhances the current understanding of the relationships between mass customization and product innovation capabilities and their joint effects on servitization (Salvador et al., 2009; Sousa and da Silveira, 2019). It provides empirical evidence that product innovation capability plays a critical role in the implementation of servitization (Bustinza et al., 2013; Sousa and da Silveira, 2017). We find that product innovation capability directly improves servitization. Although the direct impact of mass customization capability on servitization is not significant, mass customization capability enhances product innovation capability and improves servitization indirectly through product innovation capability. In addition, the findings add clarity on the roles of lean and agile practices in developing operational capabilities (Gunasekaran, 1998; Hines et al., 2004). We find that lean practices only improve product innovation capability, whereas agile practices enhance both mass customization and product innovation capabilities. The findings enhance existing knowledge of the consequences of lean and agile practices and the understanding of practices-capabilities links (Brown and Bessant, 2003; Dowlatshahi and Cao, 2006; 
Inman et al., 2011). Therefore, this study contributes to the existing knowledge on the complex interrelationships among lean and agile practices and mass customization and product innovation capabilities (Kim et al., 2012; Zhang et al., 2019). The findings also suggest researchers consider the impacts of lean and agile practices and mass customization and product innovation capabilities simultaneously to capture their synergetic effects on servitization.

\section{Conclusions}

This study finds significant direct relationship between product innovation capability and servitization and significant indirect relationships between lean and agile practices and servitization and between mass customization capability and servitization, both of which are through product innovation capability. However, the direct relationship between lean practices and mass customization capability is not significant. Although lean practices can reduce the costs of customization, they emphasize waste elimination through standardization. Therefore, lean practices may have mixed impacts on mass customization capability. The findings also show that the direct effects of lean and agile practices and mass customization capability on servitization are not significant. One possible reason is that their impacts on servitization are fully mediated by product innovation capability.

This study has four main limitations that indicate avenues for future research. First, it does not consider the impacts of supply-chain management practices, such as supply-chain relationship management, on servitization. Social capital in supply chains may affect the adoption and profitability of servitization. Therefore, future studies can investigate the impact of supply-chain management practices on servitization. Second, this study focuses on the capabilities of mass customization and product innovation. Other organizational and operational capabilities, such as integration and knowledge management capabilities, may also influence servitization. Future studies can examine how these capabilities affect servitization. Third, this study does not consider the impacts of contextual factors, such as environmental 
uncertainty and competitiveness, on servitization. The impacts of economic and business environments on servitization are an interesting topic. Last but not least, this study used cross-sectional data to estimate the relationships among manufacturing practices, operational capabilities and servitization. A study with longitudinal design is encouraged to establish causal relationships.

\section{Acknowledgement}

This research is supported by the Fundamental Research Funds for the Central Universities, UIBE (ZD3-11) and the University of International Business and Economics Graduate Research Innovation Fund No. 201958. 


\section{References}

Alegre, J., Chiva, R., 2008. Assessing the impact of organizational learning capability on product innovation performance: An empirical test. Technovation 28, 315-326.

Baines, T., Lightfoot, H., Peppard, J., Johnson, M., Tiwari, A., Shehab, E., Swink, M., 2009. Towards an operations strategy for product-centric servitization. International Journal of Operations \& Production Management 29, 494-519.

Baines, T., Bigdeli, A., Bustinza, O., Shi, V., Baldwin, J., Ridgway, K., 2017. Servitization: Revisiting the state-of-the-art and research priorities. International Journal of Operations \& Production Management 37, 256-278.

Barney, J., 1991. Firm Resources and Sustained Competitive Advantage. Journal of Management 17, 99-120.

Brouthers, L.E., O’Donnell, E., Hadjimarcou, J., 2005. Generic Product Strategies for Emerging Market Exports into Triad Nation Markets: A Mimetic Isomorphism Approach. Journal of Management Studies 42, 225-245.

Brown, S., Bessant, J., 2003. The manufacturing strategy-capabilities links in mass customisation and agile manufacturing - an exploratory study. International Journal of Operations \& Production Management 23, 707-730.

Bustinza, O.F., Parry, G.C., Vendrell-Herrero, F., 2013. Supply and demand chain management: the effect of adding services to product offerings. Supply Chain Management 18, 618-629.

Dowlatshahi, S., Cao, Q., 2006. The relationships among virtual enterprise, information technology, and business performance in agile manufacturing: An industry perspective. European Journal of Operational Research 174, 835-860.

Durach, C. F., Wiengarten, F., 2017. Environmental management: The impact of national and organizational long-term orientation on plants' environmental practices and performance efficacy. Journal of Cleaner Production 167, 749-758.

Fang, E, Palmatier, R.W., Steenkamp, J.E.M., 2008. Effect of service transition strategies on firm value, Journal of Marketing 72, 1-14.

Fornell, C., Larcker, D.F., 1981. Evaluating Structural Equation Models with Unobservable Variables and Measurement Error. Journal of Marketing Research $18,39$.

Gebauer, H., Fleisch, E., Friedli, T., 2005. Overcoming the Service Paradox in Manufacturing Companies. European Management Journal 23, 14-26.

Green, M.H., Davies, P., Ng, I.C.L., 2017. Two strands of servitization: A thematic 
analysis of traditional and customer co-created servitization and future research directions. International Journal of Production Economics 192, 40-53.

Gunasekaran, A., 1998. Agile manufacturing: Enablers and an implementation framework. International Journal of Production Research 36, 1223-1247.

Hines, P., Rich, N., Holweg, M., 2004. Learning to evolve: A review of contemporary lean thinking. International Journal of Operations \& Production Management 24, 994-1011.

Hu, L., Bentler, P.M., 1999. Cutoff criteria for fit indexes in covariance structure analysis: Conventional criteria versus new alternatives. Structural Equation Modeling: A Multidisciplinary Journal 6, 1-55.

Inman, R.A., Sale, R.S., Green, K.W., Whitten, D., 2011. Agile manufacturing: Relation to JIT, operational performance and firm performance. Journal of Operations Management 29, 343-355.

Kim, D.-Y., Kumar, V., Kumar, U., 2012. Relationship between quality management practices and innovation. Journal of Operations Management 30, 295-315.

Kowalkowski, C., Gebauer, H., Kamp, B., Parry, G., 2017. Servitization and deservitization: Overview, concepts, and definitions. Industrial Marketing Management 60, 4-10.

Kull, T.J., Yan, T., Liu, Z., Wacker, J.G., 2014. The moderation of lean manufacturing effectiveness by dimensions of national culture: Testing practice-culture congruence hypotheses. International Journal of Production Economics 153, 1-12.

Lee, S., Yoo, S., Kim, D., 2016. When is servitization a profitable competitive strategy? International Journal of Production Economics 173, 43-53.

Leite, M., Braz, V., 2016. Agile manufacturing practices for new product development: industrial case studies. Journal of Manufacturing Technology Management 27, $560-576$.

Liu, G.J., Shah, R., Babakus, E., 2012. When to Mass Customize: The Impact of Environmental Uncertainty. Decision Sciences 43, 851-887.

Neely, A., 2008. Exploring the financial consequences of the servitization of manufacturing. Operations Management Research 1, 103-118.

OECD, 2018, Trade in value-added, http://www.oecd.org/industry/ind/measuring-trade-in-value-added.htm (accessed 5.13.18).

Onofrei, G., Prester, J., Fynes, B., Humphreys, P., Wiengarten, F., 2019. The 
relationship between investments in lean practices and operational performance: exploring the moderating effects of operational intellectual capital. International Journal of Operations \& Production Management 39, 406-428.

Opresnik, D., Taisch, M., 2015. The value of Big Data in servitization. International Journal of Production Economics 165, 174-184.

Peng, D.X., Schroeder, R.G., Shah, R., 2008. Linking routines to operations capabilities: A new perspective. Journal of Operations Management 26, 730-748.

Perona, M., Saccani, N., and Bacchetti, A., 2017. Research vs. practice on manufacturing firms' servitisation strategies: A gap analysis and research agenda. Systems 5, 1-28.

Peteraf, M.A., 1993. The cornerstones of competitive advantage: A resource-based view. Strategic Management Journal 14, 179-191.

Podsakoff, P.M., MacKenzie, S.B., Lee, J.-Y., Podsakoff, N.P., 2003. Common method biases in behavioral research: A critical review of the literature and recommended remedies. Journal of Applied Psychology 88, 879-903.

Preacher, K.J., Hayes, A.F., 2008. Asymptotic and resampling strategies for assessing and comparing indirect effects in multiple mediator models. Behavior Research Methods 40, 879-891.

Qi, Y.N., 2006. Supply chain strategies and practices: an exploratory study (Doctoral dissertation). The Chinese University of Hong Kong.

Resta, B., Powell, D., Gaiardelli, P., Dotti, S., 2015. Towards a framework for lean operations in product-oriented product service systems. CIRP Journal of Manufacturing Science \& Technology 9, 12-22.

Rabetino, R., Harmsen, W., Kohtamaki, M., Sihvonen, J., 2018. Structuring servitization-related research. International Journal of Operations \& Production Management 38, 350-371.

Saccani, N., Visintin, F., Rapaccini, M., 2014. Investigating the linkages between service types and supplier relationships in servitized environments. International Journal of Production Economics 149, 226-238.

Salvador, F., Holan, P.M.D., Piller, F.T., 2009. Cracking the Code of Mass Customization. MIT Sloan Management Review 50, 71-78.

Schoenherr, T., Power, D., Narasimhan, R., Samson, D. 2012. Competitive Capabilities among Manufacturing Plants in Developing, Emerging, and Industrialized Countries: A Comparative Analysis. Decision Sciences 43, 37-71. 
Schoenherr, T., Narasimhan, R., 2012. The fit between capabilities and priorities and its impact on performance improvement: revisiting and extending the theory of production competence. International Journal of Production Research 50, 3755-3775.

Shah, R., Ward, P.T., 2007. Defining and developing measures of lean production. Journal of Operations Management 25, 785-805.

Sharifi, H., Zhang, Z., 2001. Agile manufacturing in practice - Application of a methodology. International Journal of Operations \& Production Management 21, $772-794$.

Slater, S.F., Mohr, J.J., Sengupta, S., 2014. Radical Product Innovation Capability: Literature Review. Journal of Product Innovation Management 31, 552-566.

Sousa, R. and da Silveira, G.J.C., 2017. Capability antecedents and performance outcomes of servitization: Differences between basic and advanced services. International Journal of Operations \& Production Management 39, 454-474.

Sousa, R. and da Silveira, G.J.C., 2019. The relationship between servitization and product customization strategies. International Journal of Operations \& Production Management 39, 454-474.

Vandermerwe, S., Rada, J., 1988. Servitization of business: Adding value by adding services. European Management Journal 6, 314-324.

Visnjic, I., van Looy, B., 2013. Servitization: Disentangling the impact of service business model innovation on manufacturing firm performance. Journal of Operations Management 31, 169-180.

Whybark, D.C., 1997. GMRG survey research in operations management. International Journal of Operations \& Production Management 17, 686-696.

Whybark, D.C., Sheu, C., Wacker, J.G., 2009. The Evolution of an International Academic Manufacturing Survey. Decision Line May 2009, 17-19.

Zhang, M., Guo, H., Huo, B.F., Zhao, X.D., Huang, J.B., 2019. Linking supply chain quality integration with mass customization and product modularity. International Journal of Production Economics 207, 227-235.

Zhang, M., Guo, H., Zhao, X., 2017. Effects of social capital on operational performance: impacts of servitisation. International Journal of Production Ressearch 55, 4304-4318.

Zhang, M., Lettice, F., Chan, H.K., Nguyen, H.T., 2018. Supplier integration and firm performance: the moderating effects of internal integration and trust. Production 
Planning \& Control 29, 802-813.

Zhang, M., Lettice, F., Zhao, X.D., 2015a. The impact of social capital on mass customisation and product innovation capabilities. International Journal of Production Research 53, 5251-5264.

Zhang, M., Qi, Y.N., Zhao, X.D., Duray, R., 2015b. Mass customisation systems: complementarities and performance consequences. International Journal of Logistics Research and Applications 18, 459-475.

Zhang, M., Zhao, X.D., Qi, Y.N., 2014. The effects of organizational flatness, coordination, and product modularity on mass customization capability. International Journal of Production Economics 158, 145-155. 


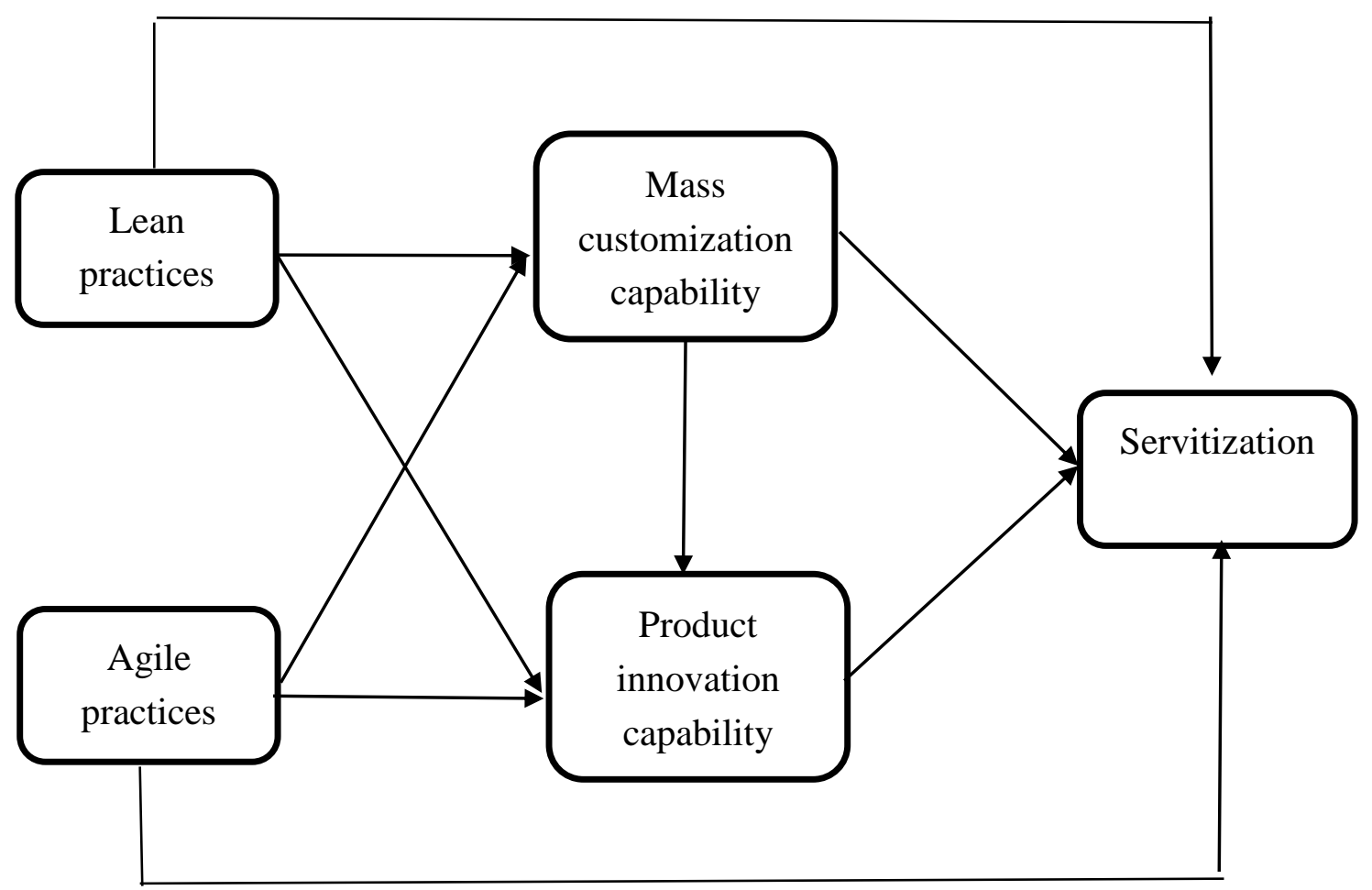

Figure 1. Conceptual framework 


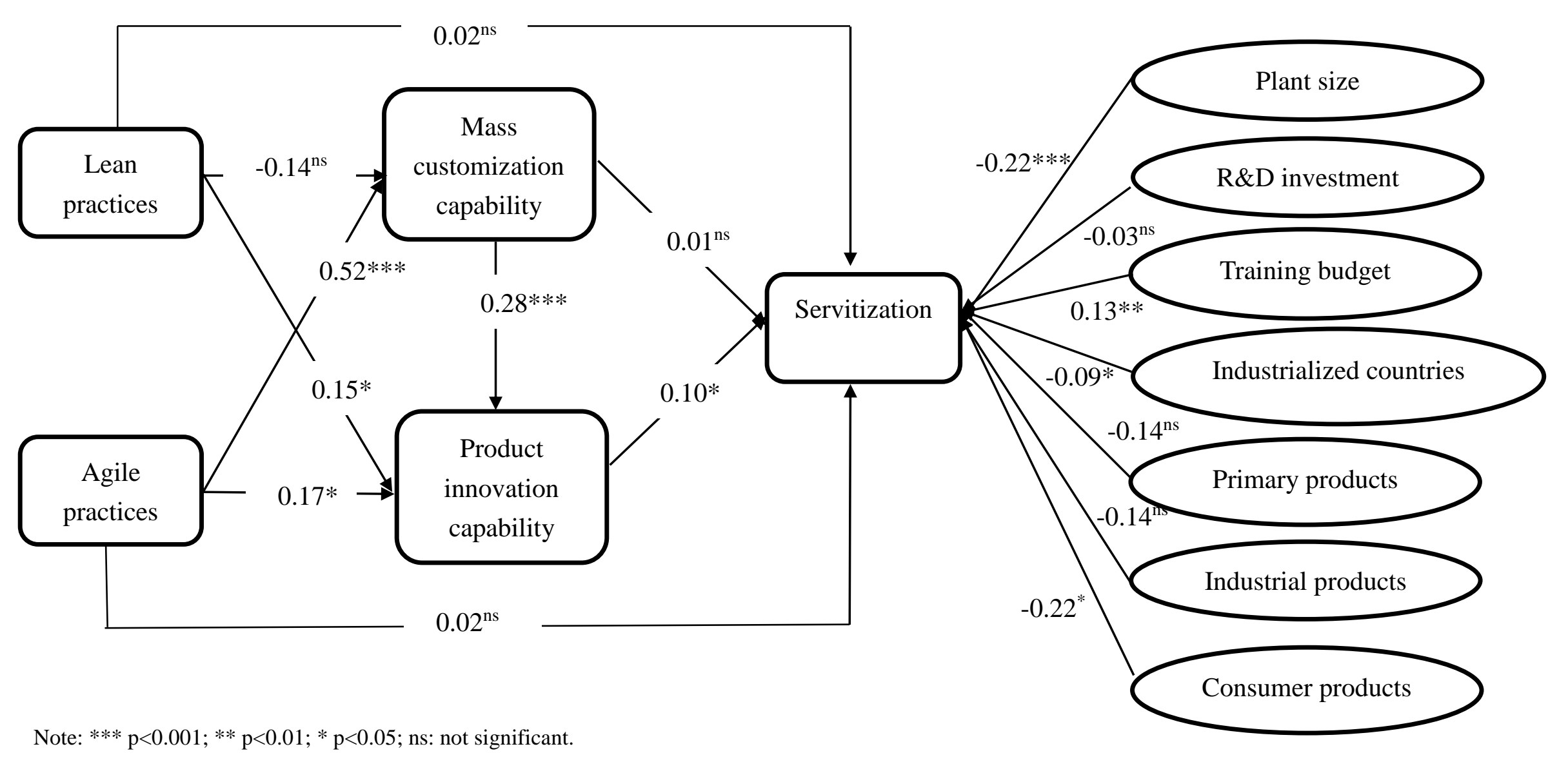

Figure 2. Results of statistical analysis 
Table 1. Demographic information

\begin{tabular}{lcc}
\hline Country Group & $\mathrm{N}$ & $\%$ \\
\hline Industrialized & 139 & $21.48 \%$ \\
Emerging & 508 & $78.52 \%$ \\
Total & 647 & $100.00 \%$ \\
Individual Countries & & \\
Industrialized & 139 & $21.48 \%$ \\
Australia & 26 & $4.02 \%$ \\
Ireland & 30 & $4.64 \%$ \\
U.S.A. & 83 & $12.83 \%$ \\
Emerging & 508 & $78.52 \%$ \\
China & 100 & $15.46 \%$ \\
Croatia & 113 & $17.47 \%$ \\
Hungary & 37 & $5.72 \%$ \\
India & 58 & $8.96 \%$ \\
Poland & 80 & $12.36 \%$ \\
Taiwan & 40 & $6.18 \%$ \\
Vietnam & 80 & $12.36 \%$ \\
\hline Industry Group & $\mathrm{N}$ & $\%$ \\
\hline Industrial products & 126 & $19.47 \%$ \\
Consumer products & 250 & $38.64 \%$ \\
Primary products & 241 & $37.25 \%$ \\
Others (those who didn't report the industry sector) & 30 & $4.64 \%$ \\
Total & 647 & $100.00 \%$ \\
\hline & & \\
\hline
\end{tabular}

\section{Individual Industries}

$\begin{array}{lcc}\text { Industrial products } & 126 & 19.47 \% \\ \text { Industrial and commercial machinery and computer equipment } & 42 & 6.49 \% \\ \text { Manufacture of other transport equipment } & 17 & 2.63 \% \\ \text { Measuring, analyzing, and controlling instruments; photographic, } & 13 & 2.01 \% \\ \text { medical and optical goods; watches and clocks } & 36 & 5.56 \% \\ \text { Miscellaneous manufacturing industries } & 18 & 2.78 \% \\ \text { Textile mill products } & 250 & 38.64 \% \\ \text { Consumer products } & 31 & 4.79 \% \\ \text { Apparel and other finished products made from fabrics and } & \end{array}$


similar materials

Electronic and other electrical equipment and components, except computer equipment

$93 \quad 14.37 \%$

Food and kindred products

$66 \quad 10.20 \%$

Leather and leather products

$6 \quad 0.93 \%$

Manufacture of motor vehicles, trailers and semi-trailers

$22 \quad 3.40 \%$

Paper and allied products,

$22 \quad 3.40 \%$

Printing, publishing, and allied industries

$10 \quad 1.55 \%$

Primary products

$241 \quad 37.25 \%$

Chemicals and allied products

$31 \quad 4.79 \%$

Fabricated metal products, except machinery and transportation equipment

$59 \quad 9.12 \%$

Furniture and fixtures

$17 \quad 2.63 \%$

Lumber and wood products, except furniture

$26 \quad 4.02 \%$

Petroleum refining and related industries

$7 \quad 1.08 \%$

Primary metal industries

$28 \quad 4.33 \%$

Rubber and miscellaneous plastics products

$48 \quad 7.42 \%$

Stone, clay, glass, and concrete products

$24 \quad 3.71 \%$

Tobacco products

$1 \quad 0.15 \%$

\begin{tabular}{lcc} 
Others & 30 & $4.64 \%$ \\
\hline Plant size (Number of employees) & $\mathrm{N}$ & $\%$ \\
\hline$<=100$ & 289 & $44.67 \%$ \\
$101-200$ & 98 & $15.15 \%$ \\
$201-500$ & 132 & $20.40 \%$ \\
$501-1000$ & 50 & $7.73 \%$ \\
$>1000$ & 78 & $12.06 \%$ \\
Total & 647 & $100.00 \%$ \\
\hline
\end{tabular}


Table 2. Descriptive statistics

\begin{tabular}{|l|c|c|c|c|c|}
\hline & LP & AP & MCC & PIC & Ser \\
\hline Lean practice (LP) & $\mathbf{0 . 7 6}$ & & & & \\
\hline Agile practice (AP) & $0.64^{* *}$ & $\mathbf{0 . 7 6}$ & & & \\
\hline $\begin{array}{l}\text { Mass customization } \\
\text { capability (MCC) }\end{array}$ & $0.23^{* *}$ & $0.36^{* *}$ & $\mathbf{0 . 8 4}$ & & \\
\hline $\begin{array}{l}\text { Product innovation } \\
\text { capability (PIC) }\end{array}$ & $0.28^{* *}$ & $0.36^{* *}$ & $0.36^{* *}$ & $\mathbf{0 . 9 1}$ & \\
\hline Servitization (Ser) & -0.03 & 0.04 & 0.06 & $0.09^{*}$ & n.a. \\
\hline Mean & 4.56 & 4.74 & 4.93 & 4.33 & 27.73 \\
\hline Standard deviation & 1.14 & 1.07 & 1.19 & 1.26 & 31.04 \\
\hline
\end{tabular}

Note: The square root of the AVE of each construct is shown on the diagonal of the matrix in bold.

n.a.: Not Available; ** correlation is significant at 0.01 level; * Correlation is significant at the 0.05 level (2-tailed). 


\section{Appendix 1. Measurement items}

\begin{tabular}{|c|c|}
\hline Measurement items & Factor loading \\
\hline Lean practices & $\begin{array}{l}\text { AVE }=0.58 ; \quad \text { CR }=0.85 \\
\alpha=0.76\end{array}$ \\
\hline $\begin{array}{l}\text { Quality management programs (e.g., TQM, } \\
\text { Six-Sigma) }\end{array}$ & $0.789(27.53)$ \\
\hline Cost reduction programs (e.g., Target Costing) & $0.730(19.55)$ \\
\hline Manufacturing lead time reduction programs & $0.774(27.58)$ \\
\hline Processing technologies (e.g., automation) & $0.751(22.70)$ \\
\hline Agile practices & $\begin{array}{l}\mathrm{AVE}=0.58 ; \quad \mathrm{CR}=0.87 \\
\alpha=0.82\end{array}$ \\
\hline Flexible workforce & $0.640(17.26)$ \\
\hline Integrating manufacturing and design processes & $0.757(31.51)$ \\
\hline Customer support & $0.772(33.72)$ \\
\hline Customer process integration & $0.856(57.78)$ \\
\hline Supplier process integration & $0.768(29.52)$ \\
\hline Mass customization capability & $\begin{array}{l}\mathrm{AVE}=0.71 ; \quad \mathrm{CR}=0.93 \\
\alpha=0.90\end{array}$ \\
\hline $\begin{array}{l}\text { We are highly capable of large-scale product } \\
\text { customization. }\end{array}$ & $0.804(36.73)$ \\
\hline $\begin{array}{l}\text { We can easily add significant product variety } \\
\text { without increasing cost. }\end{array}$ & $0.839(59.69)$ \\
\hline $\begin{array}{l}\text { We can customize products while maintaining high } \\
\text { volume. }\end{array}$ & $0.864(58.26)$ \\
\hline $\begin{array}{l}\text { We can add product variety without sacrificing } \\
\text { quality. }\end{array}$ & $0.838(40.37)$ \\
\hline $\begin{array}{l}\text { Our capability for responding quickly to } \\
\text { customization requirements is very high. }\end{array}$ & $0.877(74.72)$ \\
\hline Product innovation capability & $\begin{array}{l}\mathrm{AVE}=0.82 ; \mathrm{CR}=0.95 \\
\alpha=0.93\end{array}$ \\
\hline $\begin{array}{l}\text { Percentage of total sales stemming from new } \\
\text { products }\end{array}$ & $0.863(63.60)$ \\
\hline Number of new products & $0.911(112.96)$ \\
\hline Speed of introducing new products & $0.922(123.80)$ \\
\hline Frequency of new products introduction & $0.928(129.91)$ \\
\hline
\end{tabular}

Note: AVE: Average Variance Extracted; CR: Composite Reliability; $\alpha$ : Cronbach's $\alpha$; All t values, which are shown in the parentheses, are significant at $\mathrm{p}<0.01$ level. 